\title{
Length of Stay and Sustainability: Evidence from the Schist Villages Network (SVN) in Portugal
}

\author{
Fidel Martínez-Roget ${ }^{1, * \mathbb{C}}$, José Alberto Moutela ${ }^{2}$ and Xosé A. Rodríguez ${ }^{3}$ \\ 1 Department of Applied Economics, University of Santiago de Compostela, Avda. Xoán XIII, s/n, \\ 15782 Santiago de Compostela, Spain \\ 2 Doctoral Programme in Economics and Business, University of Santiago de Compostela, Avda. Xoán XIII, \\ s/n, 15782 Santiago de Compostela, Spain; josealberto.tavares@rai.usc.es \\ 3 Department of Quantitative Economics, University of Santiago de Compostela, Avda. Xoán XXIII, \\ s/n, 15782 Santiago de Compostela, Spain; xoseanton.rodriguez@usc.es \\ * Correspondence: fidel.martinez@usc.es; Tel.: +34-881-811-51
}

Received: 13 April 2020; Accepted: 11 May 2020; Published: 14 May 2020

\begin{abstract}
There is evidence that increasing the Length of Stay (LOS) contributes to the sustainability of destinations. This paper analyzes LOS determinants in the Schist Villages Network (SVN) in Portugal, where almost half of the visitors are same-day visitors. Given that these visitors generate more environmental impacts, an increase in LOS would help guide tourism towards more sustainable standards. The analysis was performed using several Heckman selection models. Unlike the findings of previous studies, LOS depended mainly on the characteristics of the trip and the destination - not on visitor profile - and can therefore be considered a highly specific form of tourism. Comparatively, motivations associated with rest, residents' hospitality, and local produce consumption encourage visitors to extend their stay, thereby boosting tourism sustainability. The SVN is also shown to have various cultural and heritage resources that are currently highly valued. However, the leisure offer is insufficient to increase LOS. Furthermore, conventional advertising was not shown to be effective in raising LOS compared with word-of-mouth (WOM). The paper concludes that measures should be adopted to increase the local produce offer, retain population, maintain traditional village activities, and attract visitors from nearby regions. These actions could increase overnight stays and LOS, contributing to more sustainable development.
\end{abstract}

Keywords: length of stay; sustainability; rural areas; motivation; Heckman models

\section{Introduction}

Tourism has become one of the world's most dynamic industries. International tourist arrivals have practically tripled in the last two decades, rising from 531 million in 1995 to 1401 million in 2018 [1]. Projections indicate that this growth will continue in the future, reaching 1800 million international arrivals by 2030 [2]. It is clear that tourism plays a prominent role in the economy of many regions and countries, generating positive impacts, but it is also evident that, more recently, the focus has been on its negative impacts, especially as a consequence of massification, the congestion of public space, the increasing housing rentals, the rise in $\mathrm{CO}_{2}$ emissions, and the degradation of certain natural and heritage resources [3-9].

In Europe, the expansion of tourism has occurred mainly in cities, towns, and suburbs, with rural areas accounting for only a third of the total overnight stays in the European Union between 2012 and 2018 [10]. However, a number of studies have highlighted the potential of tourism as a driving force for rural areas and its contributions to sustainable economic development and residents' well-being. Specifically, tourism is highlighted as a useful instrument for the diversification of the 
productive structure, generating income, and creating jobs, in many cases for women, which is of particular relevance in an environment where female participation in the labor market remains low. Furthermore, the creation of this type of employment contributes to reducing emigration and the depopulation of the rural environment. The role of tourism in retaining certain essential services that would disappear in its absence has also been highlighted [11-16].

In contrast, other studies have drawn attention to the limitations of tourism as an instrument for diversification and regional development [17]. Others have qualified the dimension of its impacts, which may be limited by questions such as infrastructures, accessibility, a lack of attractions, the sizes of establishments, the greater weight of domestic demand, or the low number of activities carried out by tourists in rural areas [18-24]. These limitations are an obstacle to the economic viability of businesses and condition the role of tourism as a strategy for revitalizing the rural environment.

Taking into account the dichotomy between the positive and negative effects and the limitations of tourism in rural areas, the ideal solution would be to find specific formulas for sustainable tourism in rural areas. A number of studies have indicated that sustainable tourism formulas are effective potential tools for generating income and rejuvenating traditional industries in rural areas [25-27]. Sustainability implies maximizing profit whilst minimizing environmental and social costs. Therefore, it means achieving the highest net benefits derived from tourism. Greater sustainability will boost the well-being of society while, at the same time, reducing environmental damage. In addition, sustainability will not only benefit destinations and the environment, but it will also be positive for visitors' own experiences and satisfaction levels [28].

We consider that the evolution of two variables contributes to a greater net impact of tourism in rural areas: The reduction in the percentage of same-day visitors and a longer length of stay (LOS). The higher the percentage of same-day visitors, the fewer the positive impacts and the greater the negative ones will be. It is clear that same-day visitors spend less than tourists and exert more pressure on the resources of natural areas. Firstly, accommodation is one of the most important expenditures of tourists in the destination, and secondly, non-overnight visitors tend to stay in central locations and visit major tourism attractions, putting pressure on resources [29-31].

Increasing LOS is as important in generating additional benefits as it is in reducing the negative effects of tourism [32]. Firstly, the increase in LOS will alleviate the overcrowding of certain areas while offering opportunities for others that would be left out of tourism development [33]. Secondly, the increase in LOS allows for slow consumption that encourages the creation of jobs and the conservation of local products and resources, thus contributing to sustainability [34,35]. Finally, from an environmental point of view, higher LOS implies a lower impact on the environment. Following [36], it must also be remembered that greater LOS implies carrying fewer visitors and, consequently, fewer transport infrastructure requirements, lower land needs, lower energy consumption, and lower greenhouse gas emissions $[37,38]$. Therefore, one of the main goals of tourism management agents is to design policies that encourage greater LOS.

Despite the relevance of these two factors in boosting the net impacts of tourism, we were unable to locate any papers that analyze the determinants of LOS in rural areas. To fill this gap, our empirical analysis focuses on the Schist Villages Network (SVN), a set of 27 villages located in 19 municipalities in the center of Portugal. It is an experience developed with the help of an EU community-based initiative known as the Schist Villages Network Program, which, supported by the participation of various stakeholders, has recovered the architectural and cultural heritage, generated income, and created jobs.

The main goals of this paper are to identify the LOS in the case of SVN and analyze whether the factors underlying the decision to stay overnight and those affecting the number of overnight stays differ. In this study, we use Heckman selection models that allow for the differentiation between the factors determining the decision to stay overnight and those affecting the number of overnight stays. This methodology also enables us to distinguish between same-day visitors and tourists. This paper aims to contribute to understanding of the SVN's tourism characteristics from the perspective of LOS as well as the factors behind the decision to stay overnight and those affecting the number of 
overnight stays. Determining whether these factors are the same is crucial because the economic and environmental impacts of tourists and same-day visitors are very different. Furthermore, a joint analysis of both decisions is necessary, since the number of overnight stays depends on the initial decision of whether to stay overnight or not. Finally, clarifying the drivers of both decisions allows for the formulation of policies aimed at increasing the relative weight of tourists with respect to same-day visitors, thereby increasing the sustainability of tourism. The conclusions drawn here can be extended to other rural tourist destinations characterized by a large number of same-day visitors and short average tourist stays.

\section{Length of Stay: Importance and Determinants}

There is a broad consensus in scientific literature regarding the importance of LOS in tourism management. Although some studies have found that average daily spending is higher in short stays $[39,40]$ the average spending per trip is heavily influenced by the LOS [41,42]. In addition, the LOS conditions the environmental impacts of tourism. The use of fossil fuels and the resulting emissions are the main environmental problem related to tourism [43,44]. Indeed, transport is the activity that impacts most negatively on the environment [37]. If LOS is reduced, more visitors will be required to maintain revenue, which will mean a greater use of transportation and, therefore, an increase in greenhouse gas emissions. Conversely, an increase in LOS will increase economic benefits without increasing environmental damage $[31,38,45]$. At the same time, an increase in LOS will allow tourists to abandon the usual circuits in the destination, thereby benefiting more peripheral locations [33].

The decision whether or not to stay overnight has important consequences in terms of economic or environmental impacts. When comparing same-day visitors and tourists, the latter spend more because accommodation expenditure is a key component of overall tourist spending in a destination [46]. In addition, same-day visitors have a limited time and, therefore, they focus on the main attractions [47], which, as Reference [36] (p. 2089) noted, makes it difficult "to distribute tourism's benefits to a greater number of stakeholders, specifically in more peripheral regions". This means that the socioeconomic impacts are fewer in the case of same-day visitors, and the negative impacts on natural and heritage resources increase.

In recent years, evidence has pointed to a downward trend in LOS [36,48,49]. Taking into account this trend and the importance of LOS for destinations, a significant number of studies have focused on the study of LOS and its determining factors. As examples, we will cite some of the most relevant works that have been published in the last decade.

In research focused on low-cost tourism in Catalonia (Spain), Reference [50] used duration models to analyze the determinants of LOS, identifying as significant factors nationality, age, education, type of occupation, type of accommodation, season of travel, and destination area. In turn, Reference [51] analyzed LOS in Spain with a random-parameter logit model. Their empirical results indicated that income, household size, age, distance, motivations, size of the city of origin, and available days are significant factors. In addition to some determinants previously referred to, such as age and education, Reference [29], using duration models, identified other significant determinants, such as the type of hotel, the prime motivation for trip, events, climate, the beach, and hospitality, when they analyzed LOS in the golf tourism segment in the Algarve (Portugal). Reference [52] used a truncated Poisson regression to analyze LOS in the Balearic Islands (Spain) and found familiarity with the destination, the number of tourist trips, and the number of people in the group to be significant determinants. In an analysis of LOS in Madagascar, Reference [53] used duration models and found that nature, gastronomy, the sea, life style, the physical appearance of the population, and security were relevant factors.

When analyzing factors influencing the LOS in cultural tourism in Bolzano (Italy) using a zero-truncated negative binomial model, Reference [54] identified the costs associated with the journey to be a key element. The analysis of LOS in senior tourism conducted by [55], based on a negative binomial model, revealed that factors such as visiting friends and relatives, accommodation type, lone travel, and certain activities were all significant. In an analysis of the LOS in Brazil with 
duration models, Reference [56] identified the following significant determinants: Multi-destination travel, travel purpose, transport mode, type of accommodation, group size, previous visits, season, expenditure, and type of destination. Reference [57] analyzed LOS in the segment of student tourism and found booking time, daily trip costs, the tourism and trip motivations, the gender, and the trip month to be significant factors. He used the ordinary least squares model, the zero-truncated negative binomial model, and the Weibull survival model. In a project focused on international tourism in south-west Norway, Reference [31] explored the aspects influencing planning LOS using a binary logistic regression, finding that perceptions of the time 'needed' for desired activities, limited holiday leave, and budgets were the most important aspects. Finally, Reference [30] analyzed the factors influencing LOS in the city of Santiago de Compostela (Spain) using five alternative Heckman selection models. The results of their work show that different factors related to tourists, travel, and the destination itself significantly determine LOS. More specifically, they found that foreign visitors traveling for business or MICE (Meetings, Incentives, Conferences and Exhibitions) reasons are the most likely to stay for longer periods.

Although there are many studies analyzing the tourism demand in rural areas [58-60], including some that focus on the determining factors of spending [61], we failed to find any that focus exclusively on analyzing LOS determinants. For this reason, we consider that our work is pioneering in its nature and that the results shed light on LOS determinants in rural areas.

\section{Materials and Methods}

\subsection{Study Area Description}

The Schist Villages Network (SVN) is situated in the center of Portugal (Figure 1). Supported by several public programs and initiatives, the SVN project originated in 2000. The project has evolved over the years, and the network currently comprises 27 villages. One of the strengths of the SVN area is its natural and historical environment with ample opportunities for use as a tourist resource, which caters to the growing demand in the rural tourism segment. This demand, which, in many cases, originates in cities, seeks leisure in contact with nature, the local population, and the endogenous territorial resources. The SVN allows the tourists to enjoy nature and discover the region's cultural traditions.

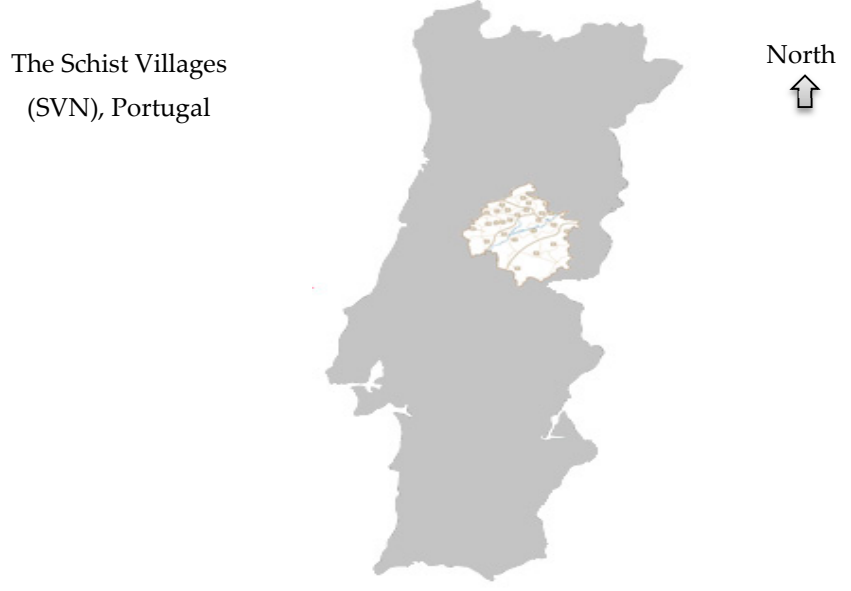

Figure 1. Location of the scope of study.

The SVN is an example of collaboration between the various stakeholders: The administration, private companies, and the local population. The Network's action lines include the revalorization of cultural heritage and the use of built architectural heritage and endogenous resources [62]. In this sense, houses were rehabilitated and infrastructures were built, fostering the socioeconomic fabric and a renewal of the arts and crafts. A differentiated tourism brand was also created for the Network based 
on the authentic values of the endogenous resources as intangible cultural heritage and deeply rooted customs [63-66].

A total of 70 establishments make up the network's accommodation offer, totaling nearly 1000 beds. Tourists' demand for regional gastronomy is covered by a group of 13 restaurants that are members of the Network, which also includes 18 "Schist Villages Shops", where a wide range of local produce and traditional handicrafts can be acquired. Moreover, the Network territory features around $700 \mathrm{~km}$ of walking trails through magnificent country and mountain landscapes, as well as $900 \mathrm{~km}$ of bicycle routes, with different levels of difficulty supported by six Mountain Bikes (MTB) centers. The region has 50 river beaches where bathing is possible in summer [67]. The villages offer a varied recreation program throughout the year, tailored to the specific characteristics of each season. There is also space for activities that encourage tourists' contact with culture, local heritage, and the authenticity of the population and local customs.

\subsection{Questionnaire Survey and Data}

The survey instrument consisted of a questionnaire divided into three main sections. Section 1 consisted of a set of questions designed to identify visitors' previous experiences in the SVN and how they heard about the Network. Section 2 included a set of questions intended to assess the SVN's prior image as well as visitors' motivations and satisfaction levels. Section 3 included a miscellaneous set of questions covering aspects such as the tourists' profile, the trip characteristics, and the destination characteristics.

The survey instrument was revised and finalized in accordance with feedback from a pilot sample of 15 visitors to the SVN. The final questionnaire included two types of questions. On the one hand, a nominal scale was used for the questions related to the visitor's profile, the travel characteristics, and destination characteristics. On the other hand, in the questions related to previous image, motivation, and satisfaction, the respondents were asked to rate their evaluations on a five-point Likert-type scale.

In this study, previous image and satisfaction were assessed using a single-item method, and the respondents were asked to rate their previous image and satisfaction with the activities and overall travel experience on a five-point Likert scale $(1=$ very dissatisfied and $5=$ very satisfied $)$. For motivation, 13 items were rated on a five-point Likert scale, where $1=$ most disagree and $5=$ most agree. An exploratory factor analysis (EFA) was conducted to identify the underlying dimensions of visitors' motivation, and the arithmetic means of items included within each factor obtained were used in the subsequent analysis.

It is widely accepted that motivation is one of the central elements in both the choice process and tourist behavior at the destination [68]. There is a broad consensus that there are both "push motivation" and "pull motivation" factors [69,70]. Push motivation is related to internal elements, typical of tourists, and includes factors such as relaxation, quest for knowledge, and family togetherness. Pull factors depend on the destination's appeal and include elements such as the range of activities on offer, natural or cultural attractions, security, or accessibility [68,71,72].

SPSS (ver. 20.0) was used for the exploratory factor analysis (EFA). A four-factor solution with eigenvalues greater than one and a factor loading above 0.5 , accounting for $66.63 \%$ of the total variance, was chosen. Factor loadings of variables varied from 0.61 to 0.85 . This study therefore meets the criteria suggested by [73] (pp. 122-129) (factor loadings equal to or above 0.50, eigenvalues equal to or above 1.0, and results of the factor analysis explaining at least $60 \%$ of the total variance) [27]. Cronbach's $\alpha$ for the four dimensions ranged from 0.68 to 0.79 , indicating high internal consistency and a generally agreed upon lower limit of 0.60 for research at the exploratory stage [74]. The results show a wide variety of motivations for visitors in rural areas.

As can be seen in Table 1, factor 1 exhibited most of the variance (32.61\%) with a reliability coefficient of 0.79 . This factor incorporated four items of motivation (security and comfort; rest, leisure, and relaxation; local people's affectivity and friendliness; and local operators' availability and 
friendliness). The proportion of the total variance explained for this factor leads us to conclude that among rural visitors of the SVN, relaxation is a central motivational differentiation factor. The results coincide with the work of [75] for Korea. This factor is related to visitors' internal emotional factors, reflecting a strong push motivation, but also a pull motivation related to residents' hospitality. We have named this factor "relaxation and hospitality". Factor 2 accounted for approximately $13 \%$ of the variance in data and incorporates four items related to the natural, architectural, heritage, and cultural attractions of the destination. We identified it as "natural and cultural attractions". Factor 3 accounted for $11.41 \%$ of the variance and included leisure and sporting activities, sightseeing tours, regional cuisine, and catering diversity. This factor was therefore termed "sports and activities". Finally, factor 4, identified as "local produce", accounted for approximately $9.61 \%$ of the variance in the data. This factor reflects a strong push motivation that reflects visitors' preference for consuming local produce during their trips and their willingness to pay for them.

Table 1. Factor analysis of motivations of Schist Villages Network (SVN) visitors.

\begin{tabular}{|c|c|c|c|c|c|}
\hline Factor or Items & Fact. Load. & Eigenval. & Var. Explain. (\%) & $\begin{array}{l}\text { Cum. Var. } \\
\text { Explain. (\%) }\end{array}$ & $\begin{array}{c}\text { Cronbach } \\
\alpha\end{array}$ \\
\hline Relaxation and hospitality $\left(\right.$ Mot $\left._{1}\right)$ & & 4.24 & 32.61 & 32.61 & 0.79 \\
\hline Security and comfort & 0.84 & & & & \\
\hline \multirow{3}{*}{$\begin{array}{c}\text { Rest, leisure, relaxation } \\
\text { Local people's affectivity and friendliness } \\
\text { Local operators' availability and } \\
\text { friendliness }\end{array}$} & 0.75 & & & & \\
\hline & 0.69 & & & & \\
\hline & 0.63 & & & & \\
\hline Natural and cultural attractions $\left(\operatorname{Mot}_{2}\right)$ & & 1.69 & 13.01 & 45.61 & 0.77 \\
\hline Contact with nature & 0.85 & & & & \\
\hline Natural and landscape resources & 0.79 & & & & \\
\hline Traditional conserved architecture & 0.72 & & & & \\
\hline Cultural and traditional heritage & 0.61 & & & & \\
\hline Sports and activities $\left(\mathrm{Mot}_{3}\right)$ & & 1.48 & 11.41 & 57.02 & 0.68 \\
\hline Program of leisure and sporting activities & 0.80 & & & & \\
\hline Sightseeing tours & 0.70 & & & & \\
\hline \multirow{4}{*}{$\begin{array}{l}\text { Regional cuisine and catering diversity } \\
\text { Local produce (Mot } \text { M }_{4} \\
\text { I am willing to pay more for local produce } \\
\text { I prefer to consume local produce when } \\
\text { I travel }\end{array}$} & 0.62 & & & & \\
\hline & & 1.25 & 9.61 & 66.63 & 0.71 \\
\hline & 0.84 & & & & \\
\hline & 0.82 & & & & \\
\hline
\end{tabular}

The survey included questions to determine whether or not the visitor had stayed overnight and, in case he/she had, the number of nights. With these answers, we defined two alternative dependent variables: length1, a binary variable indicating whether or not the visitor stayed overnight, and length2, a discrete numerical variable reflecting the number of nights the trip included. In relation to the determinants of the LOS at the destination, the covariates included in this study were classified into three categories:

a. Visitor-based variables: Age, gender, education, occupation, and monthly income.

b. Travel-based variables: Motivation; visitor origin, which defines the distance to the region of SVN (distance); the duration of the trip to the SVN in hours (duration); whether the visitor was travelling as part of a family group or not (family); if they were repeating their visit (repeat); and the number of villages visited during the trip (visits).

c. Destination-based variables: How the visitor heard about the destination (promotion); region in which the village is located (region); physical morphology of the region (mountain); village population size (size); existence of stores selling local produce, Schist Villages Shops, loja in Portuguese (shop); village specialization in tourism (tourist activity); the previous image of the SVN (image); satisfaction with activities (activities); and overall satisfaction with the visit (satisfaction).

The target population comprised visitors to the SVN located in central Portugal. The empirical study was conducted between July and November 2017. After screening the responses and removing unusable questionnaires, 427 valid questionnaires were obtained. There was a sample error of $4.7 \%$ considering a maximal variance with $\mathrm{p}=\mathrm{q}=0.5$ and a level of confidence of $95 \%$. 


\subsection{Empirical Analysis}

LOS is the factor that differentiates a same-day visitor from a tourist in a specific destination. The analysis of LOS determinants is therefore of key importance. In order to estimate the relationship between LOS and its determinants, a specific econometric model is required. The following multiple linear regression model is a suitable starting point:

$$
\text { length } X_{i}^{\prime} \beta+\varepsilon_{i}
$$

where length $h_{i}$ is the LOS for the $i$ th visitor $(i=1,2, \ldots \mathrm{N}), X_{i}^{\prime}$ denotes a vector of determinants (personal and travel characteristics, destination attributes, and other determinants), $\beta$ is the vector of parameters to be estimated, and $\varepsilon_{\mathrm{i}}$ is the disturbance.

The standard regression model (1) is not suitable for our objectives, since it does not allow us to differentiate between a same-day visitor and a tourist. Furthermore, it fails to take into account that the decision regarding the number of overnight stays is nested in the decision to stay overnight (the former depends on the latter), nor does it allow for any variations between the factors influencing the decision to stay overnight or not and those with the potential to influence the number of overnight stays (LOS). A more flexible and attractive model is therefore necessary to take all three aspects into account.

From an econometric point of view, a Heckman selection model is a feasible alternative [76,77]. The Heckman selection model was used for the first time to estimate LOS by [30]. This model consists of two equations: A selection equation to determine whether an individual stays overnight or not:

$$
\text { length } 1_{i}^{*}=X_{1 i}^{\prime} \beta_{1}+\varepsilon_{1 i} \text { where length } 1_{i}=\left\{\begin{array}{l}
1 \text { if length } 1_{i}^{*}>0 \\
0 \text { if length } 1_{i}^{*} \leq 0
\end{array}\right.
$$

and an outcome equation to estimate the number of overnight stays:

$$
\text { length } 2_{\mathrm{i}}^{*}=\mathrm{X}_{2 \mathrm{i}}^{\prime} \beta_{2}+\varepsilon_{2 \mathrm{i}} \text { where length } 2_{\mathrm{i}}=\left\{\begin{array}{r}
\text { length } 2_{\mathrm{i}}^{*} \text { if length } 1_{\mathrm{i}}^{*}>0 \\
\text { Not observed if length } 1_{\mathrm{i}}^{*} \leq 0
\end{array}\right.
$$

It is commonly assumed that $\varepsilon_{1 \mathrm{i}}$ and $\varepsilon_{2 \mathrm{i}}$ have a bivariate normal distribution:

$$
\left(\begin{array}{c}
\varepsilon_{1 i} \\
\varepsilon_{2 i}
\end{array}\right) \approx \mathrm{NID}\left(\left(\begin{array}{l}
0 \\
0
\end{array}\right),\left(\begin{array}{cc}
\sigma_{1}^{2} & \sigma_{12} \\
\sigma_{12} & \sigma_{2}^{2}
\end{array}\right)\right)
$$

where $\sigma_{1}^{2}=1, \sigma_{12}=\rho_{12} \sigma_{2}$, and $\rho_{12}$ is the correlation coefficient between the two disturbances.

The equation in (2) is, in fact, a standard probit model, describing the choice of staying overnight or not. The choice to stay overnight is affected by variables in $X_{1 i}$ with coefficients $\beta_{1}$. The Equation (3) describes the number of overnight stays as a function of the variables in $X_{2 i}$ with coefficients $\beta_{2}$. In principle, the variables in $X_{1 i}$ and $X_{2 i}$ can be different, and the signs and magnitudes of the $\beta$ coefficients may differ across the two equations [78].

According to [79], this model might be estimated by maximum likelihood, but due to the difficulty in maximizing its likelihood function (from an empirical point of view, this method often involves difficulties regarding the convergence of the problem [80]), in our empirical work, a two-step procedure proposed by [77], often called the Heckman two-step method (HTSM) or Heckit method, was carried out. This method is computationally simpler and provides consistent estimators, making it one of the most commonly used procedures in empirical micro-econometric work [78]. Stage one of the HTSM consists of estimating the Equation (2) by maximum likelihood as an independent probit model to determine the decision to stay overnight or not (the estimation is made using the entire sample). Then, a vector of inverse Mills ratios is generated from the parameter estimates $\lambda_{i}=\phi\left(X_{1 i}^{\prime} \beta_{1}\right) / \Phi\left(X_{1 i}^{\prime} \beta_{1}\right)$, where $\phi$ and $\Phi$ are the standard normal density and cumulative distribution function, respectively. 
In the second stage, and using only the data for overnight visitors (tourists), the least squares regression of length $2_{i}$ on $\mathrm{X}_{2 \mathrm{i}}^{\prime}$ and $\lambda$ is then computed, yielding consistent estimates of $\beta_{2}$ and $\sigma_{12}$ :

$$
\text { length } 2_{i}=X_{2 i}^{\prime} \beta_{2}+\sigma_{12} \lambda_{i}+v_{i}
$$

where $v_{i}$ is the disturbance in this equation. According to [78], a crucial parameter in (5) is covariance $\left(\sigma_{12}\right)$. Only if $\sigma_{12}=\rho_{12}=0$ could we simply estimate Equation (3) by OLS (Ordinary Least Squares) and ignore Equation (2). A simple selection bias in the OLS estimator arises if $\sigma_{12} \neq 0$.

Another key empirical question in the use of HTSM is the identification of the model (identification of $\beta_{2}$ in the second step). According to [78], for this method to work properly in practice, it is necessary to introduce exclusion restrictions in the model (that is, variables existent in $X_{1 i}$ are excluded from $X_{2 i}$ ). In the case where $X_{1 i}$ and $X_{2 i}$ are identical, the model is only identified through the fact that $\lambda_{i}$ is a nonlinear function, and the working of HTSM will depend on the variation of $\lambda_{i}$ in the sample (for example, if $\lambda_{i}$ does not vary much in the sample, then this term can be effectively approximated by a linear function of $X_{1 i}$, which can introduce severe collinearity among the regressors in Equation (5) [80]); hence, the importance of additionally introducing exclusion restrictions in order to solve the identification problem. However, there is no practical rule to specify which variables are most appropriate in order to establish the corresponding exclusion restrictions. An alternative is to use those variables that have a significant effect on the probability of staying overnight (as good predictors of length $1_{i}^{*}$, they would be included in $X_{1 i}$ ), but do not have an effect on the number of overnight stays (not associated with length ${ }_{i}$, and therefore not included in $X_{2 i}$ ). This alternative for the HTSM to be operative at an empirical level is in line with the proposal made by [30,81], among others.

Taking into account that there are no natural variable candidates to establish the exclusion restrictions [78] and, therefore, the results may be sensitive to the chosen specification, our modeling proposal consists of several alternative empirical models (as a consequence of establishing several alternative exclusion restrictions) to compare the results obtained. If the results from the different models are similar, they can be considered to be more robust and meaningful.

\section{Results}

\subsection{Descriptive Analysis}

From the statistics summary reported in Table 2, we can obtain the socio-demographic characteristics and an approximate travel profile of visitors to the SVN. Around $48 \%$ of the 427 respondents were same-day visitors. The average LOS of the $52 \%$ who stay overnight in the SVN is around 5.8 days. The number of men and women is similar, and a large majority of visitors (more than $73 \%$ ) were between 20 and 49 years old. Over half had university studies, $70 \%$ were employed, and only $9 \%$ had a monthly income of more than 3000 euros.

Most of the visitors came from two areas of Portugal. Thirty-seven percent (distance1) came from the center of Portugal, the region closest to the villages, and 38\% came from the south of Portugal, Lisbon, and the Portuguese islands. The average duration of the journey to the SVN was $4.3 \mathrm{~h}$, although it ranged from 0.5 to $28 \mathrm{~h}$. Approximately $68 \%$ of visitors had travelled to the SVN region previously. The average number of villages visited was five, with those located in Serra da Lousá and Zêzere receiving the highest number of visitors. Most of the visitors heard about the SVN from friends or relatives, had a fairly favorable previous image of the SVN, and expressed a high degree of satisfaction with the visit. 
Table 2. Descriptive statistics summary.

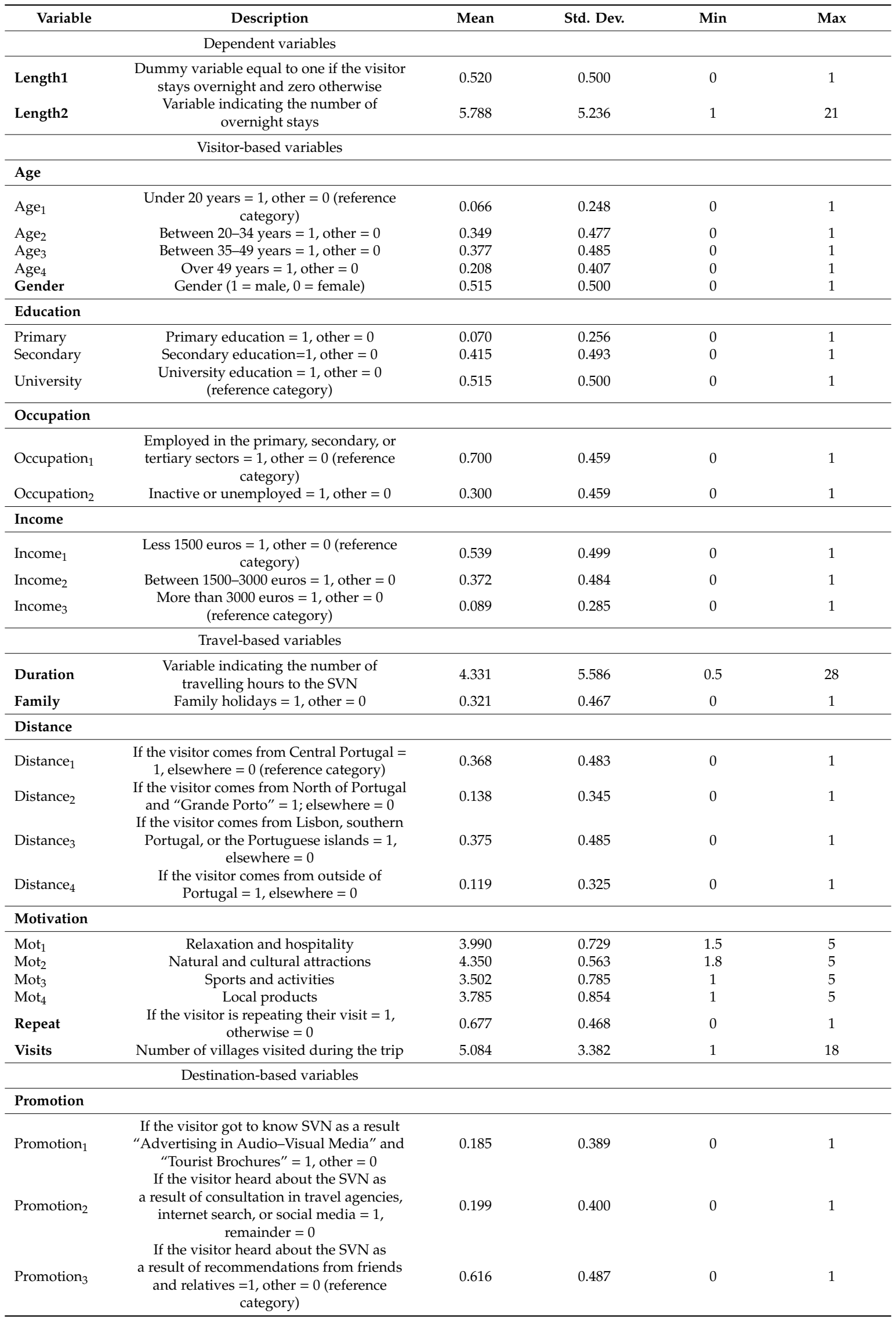


Table 2. Cont

\begin{tabular}{|c|c|c|c|c|c|}
\hline Variable & Description & Mean & Std. Dev. & Min & Max \\
\hline \multicolumn{6}{|l|}{ Region } \\
\hline Region $_{1}$ & $\begin{array}{l}\text { If the village is located in the "Serra da } \\
\text { Lousá" }=1 \text {, elsewhere }=0\end{array}$ & 0.321 & 0.467 & 0 & 1 \\
\hline Region $_{2}$ & $\begin{array}{l}\text { If the village is located in the "Serra do } \\
\qquad \text { Açor" }^{\prime} 1 \text {, elsewhere }=0\end{array}$ & 0.204 & 0.403 & 0 & 1 \\
\hline Region $_{3}$ & $\begin{array}{c}\text { If the village is located in "Tejo-Ocreza" }=1, \\
\text { elsewhere }=0\end{array}$ & 0.110 & 0.313 & 0 & 1 \\
\hline Mountain & $\begin{array}{c}\text { If the village is located in a mountain area }= \\
\qquad 1, \text { elsewhere }=0\end{array}$ & 0.522 & 0.500 & 0 & 1 \\
\hline Size & $\begin{array}{l}\text { If the population of village is under } 100 \\
\text { inhabitants }=1 \text {, other }=0\end{array}$ & 0.532 & 0.500 & 0 & 1 \\
\hline Image & $\begin{array}{c}\text { Variable indicating the previous image of } \\
\text { the village }\end{array}$ & 3.948 & 0.809 & 1 & 5 \\
\hline Activities & $\begin{array}{l}\text { Variable indicating degree of satisfaction } \\
\text { with the activities during the visit }\end{array}$ & 3.726 & 0.973 & 1 & 5 \\
\hline Satisfaction & $\begin{array}{l}\text { Variable indicating the overall satisfaction } \\
\text { with the SVN region }\end{array}$ & 4.110 & 0.744 & 1 & 5 \\
\hline
\end{tabular}

\subsection{Model Results}

As a first approach, we estimate the model assuming that there is no sample selection problem $\left(\sigma_{12}=0\right)$. Under this assumption, Equations (2) and (3) can be estimated independently. Equation (2) is estimated by maximum likelihood as a probit model to determine the decision to stay overnight or not (the estimation is made with the entire sample), and we were able to estimate Equation (3) by OLS as a truncated regression to determine the number of overnights (using only the sample information of the overnight visitors). The results are presented in the first two columns of Table 3.

Table 3. Estimation results of probit and truncated regressions and five alternative Heckman models (outcome equations).

\begin{tabular}{|c|c|c|c|c|c|c|c|}
\hline Models: & Probit Regression & $\begin{array}{l}\text { Truncated } \\
\text { Regression }\end{array}$ & Heckman1 & Heckman2 & Heckman3 & Heckman4 & Heckman 5 \\
\hline $\begin{array}{l}\text { Dependent } \\
\text { variables: }\end{array}$ & Length1 & Length2 & Length2 & Length2 & Length2 & Length2 & Length2 \\
\hline constant & 0.331 & 0.253 & -0.207 & -0.652 & -0.346 & -0.316 & 0.197 \\
\hline $\mathrm{Age}_{2}$ & $\begin{array}{c}-0.396 \\
(-0.157)\end{array}$ & 0.259 & $\begin{array}{c}-0.067 \\
(-0.549)\end{array}$ & $\begin{array}{c}-0.118 \\
(-0.762)\end{array}$ & $\begin{array}{c}0.076 \\
(-0.226)\end{array}$ & $\begin{array}{c}-0.112 \\
(-0.652)\end{array}$ & $\begin{array}{c}-0.030 \\
(-0.376)\end{array}$ \\
\hline $\mathrm{Age}_{3}$ & $\begin{array}{c}-0.304 \\
(-0.121) \\
\end{array}$ & 0.312 & $\begin{array}{c}0.161 \\
(-0.209) \\
\end{array}$ & $\begin{array}{c}0.089 \\
(-0.405) \\
\end{array}$ & $\begin{array}{c}0.264 \\
(0.032) \\
\end{array}$ & $\begin{array}{c}0.123 \\
(-0.291) \\
\end{array}$ & $\begin{array}{c}0.109 \\
(-0.157) \\
\end{array}$ \\
\hline $\mathrm{Age}_{4}$ & $\begin{array}{c}-0.444 \\
(-0.175)\end{array}$ & 0.469 & $\begin{array}{c}0.305 \\
(-0.236)\end{array}$ & $\begin{array}{c}0.138 \\
(-0.584)\end{array}$ & $\begin{array}{c}0.355 \\
(0.016)\end{array}$ & $\begin{array}{c}0.259 \\
(-0.346)\end{array}$ & $\begin{array}{c}0.290 \\
(-0.098)\end{array}$ \\
\hline Gender & $\begin{array}{c}0.018 \\
(0.007)\end{array}$ & -0.849 & $\begin{array}{c}-0.776 \\
(-0.754)\end{array}$ & $\begin{array}{c}-0.761 \\
(-0.732)\end{array}$ & $\begin{array}{c}-0.851 \\
(-0.837)\end{array}$ & $\begin{array}{c}-0.771 \\
(-0.746)\end{array}$ & $\begin{array}{c}-0.753 \\
(-0.737)\end{array}$ \\
\hline Occupation $_{2}$ & $\begin{array}{c}-0.194 \\
(-0.077) \\
\end{array}$ & -0.088 & $\begin{array}{c}-0.195 \\
(-0.431) \\
\end{array}$ & $\begin{array}{c}-0.222 \\
(-0.538) \\
\end{array}$ & $\begin{array}{c}-0.171 \\
(-0.3192) \\
\end{array}$ & $\begin{array}{l}-0.221 \\
(-.485) \\
\end{array}$ & $\begin{array}{c}-0.180 \\
(-0.349) \\
\end{array}$ \\
\hline Income $_{1}$ & $\begin{array}{c}-0.363 \\
(-0.144)\end{array}$ & -0.510 & $\begin{array}{c}-0.824 \\
(-1.266)\end{array}$ & $\begin{array}{c}-0.876 \\
(-1.466)\end{array}$ & $\begin{array}{c}-0.716 \\
(-0.993)\end{array}$ & $\begin{array}{l}-0.837 \\
(-1.33)\end{array}$ & $\begin{array}{c}-0.656 \\
(-0.973)\end{array}$ \\
\hline Income $_{2}$ & $\begin{array}{c}-0.284 \\
(-0.113)\end{array}$ & -0.861 & $\begin{array}{c}-1.090 \\
(-1.436)\end{array}$ & $\begin{array}{c}-1.150 \\
(-1.612)\end{array}$ & $\begin{array}{c}-1.008 \\
(-1.225)\end{array}$ & $\begin{array}{c}-1.096 \\
(-1.483)\end{array}$ & $\begin{array}{c}-0.971 \\
(-1.219)\end{array}$ \\
\hline
\end{tabular}


Table 3. Cont.

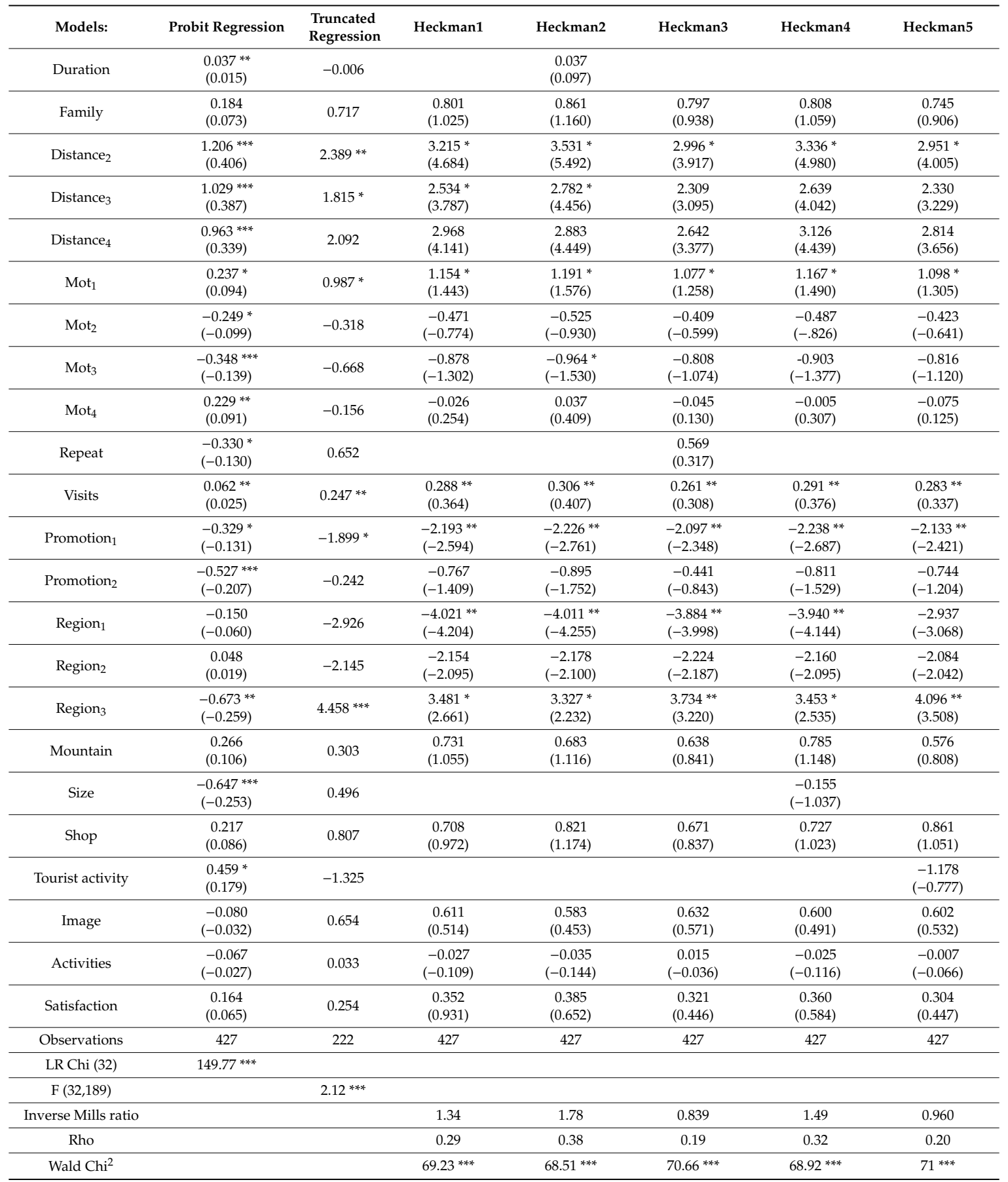

Note: All estimations carried out in Stata 14. Figures in parentheses are marginal effects. ${ }^{*},{ }^{* *}$ and ${ }^{* * *}$ refer to significance level at $10 \%, 5 \%$ and $1 \%$, respectively.

These results are of considerable interest for two reasons: firstly, because they anticipate that the factors that affect the probability of staying overnight and the number of overnight stays may differ and may have very different effects in relation to the two decisions, even of different signs. Secondly, they allow us to follow an empirical criterion to select the variables that are likely to be chosen to establish the corresponding exclusion restrictions; namely, the variables that significantly affect the probability of staying overnight (probit regression), but do not have a significant effect on the number of overnight stays in truncated regression. Four of the variables satisfy this condition: Duration, repeat, size, and tourist activity. 
In the event of a sample selection problem $\left(\sigma_{12} \neq 0\right)$, models (2) and (3) cannot be estimated independently. In this situation, to obtain consistent estimators, we have to use the HTSM. In the last five columns of Table 3, the results obtained by this method are given considering alternative exclusion restrictions: In the model Heckman1, the exclusion restrictions are established by duration, repeat, size, and tourist activity; in Heckman2, the exclusion restrictions are established by repeat, size, and tourist activity; in Heckman3, using the variables duration, size, and tourist activity; in Heckman4, using the variables duration, repeat, and tourist activity; and, finally, in Heckman5, using duration, repeat, and size. The first result of interest is that in the five models, the inverse Mills ratio term is statistically insignificant or, in other words, the hypothesis $\mathrm{H}_{0}: \sigma_{12}=\rho_{12}=0$ cannot be rejected. Consequently, there is no sample selection problem, indicating that the results of the truncated regression can be considered consistent and, therefore, could be suitable for explaining the number of overnight stays (Length2).

The results presented in Table 3 allow us to analyze the decisions to stay overnight or not and the number of overnight stays where appropriate. To study the effect of each of the explanatory variables on the probability of overnight stay, the results of probit regression can be used (column 1 of Table 3). To analyze the effect of these regressors on the number of overnight stays, the results of the other six models can be used (the truncated regression in Table 3, column 2, and the five Heckman models in Table 3, the last five columns). When examining the results, we noticed that the variables related to the visitor profile (age, gender, education, occupation, and income) do not have a significant influence on the decision to stay overnight or the number of overnight stays. On the contrary, and with the exception of the travelling companions (family), travel-related variables significantly influence the decision to stay overnight at the destination. Obviously, the longer journey to the destination, the greater the probability of staying overnight. Similarly, visitors from central Portugal-those who come from nearer places-are those who comparatively have a lower probability of staying overnight at the SVN. Visitors who come from the North of Portugal and the Porto area have a higher probability of staying overnight at the SVN and, in all models, also show a greater tendency to a greater LOS at the destination. Visitors with motivations related to rest and those with a preference for consuming local produce are most likely to stay overnight in the SVN. Compared to first-time SVN visitors, repeaters are less likely to stay overnight at the destination. Finally, the greater the number of villages visited, the greater the chances of staying overnight at the destination. In addition, the number of villages visited significantly influences the LOS.

Destination-based variables, such as promotion, the region where the village is located, the size of the village, and the importance of tourism activities in the village, significantly influence the probability of staying overnight in the SVN. Comparing institutional promotion and visitors' own information searches, recommendations by friends and relatives significantly influence the decision to stay overnight. Institutional promotions through advertising in audio-visual media and tourist brochures have the lowest impact on increasing LOS in the SVN. Compared to region 4 (Zêzere), the probability of staying overnight is lower in villages located in region 3 (Tejo-Ocreza). In the event that visitors stay overnight in one of the villages, LOS is higher in this region. Finally, the larger the village population (size) and the greater the importance of tourism in the village's economic structure (tourist activity), the greater the probability that visitors will stay overnight at the destination. Variables such as the situation of the village in a mountain area (mountain), the existence of a local produce store (shop), the previous image of the destination (image), or satisfaction do not significantly influence the decision to stay overnight or the LOS.

\section{Discussion and Conclusions}

Tourism has been shown as an effective instrument for the sustainable development of rural areas, although its effects depend on the type of visitors (same-day visitors or tourists) and, in the case of tourists, on their length of stay (LOS). Same-day visitors spend only a few hours in the destination; therefore, their expenditure is lower than that of tourists [82]; moreover, environmental costs are 
higher, as visits are concentrated at the major attractions. Therefore, a key sustainability strategy for destinations with a high percentage of same-day visitors, should be to get visitors to stay overnight for at least one night.

In the case of tourists, a longer duration of stay contributes to greater efficiency in destinations in three ways. Firstly, a higher LOS generates similar income levels with fewer tourists. Secondly, it means that tourists can visit areas outside the usual circuits, ensuring a more even distribution of benefits within the region. Finally, from an environmental point of view, higher LOS implies lower costs, as fewer tourists are required to maintain income levels, thereby reducing $\mathrm{CO}_{2}$ emissions generated by transport. Consequently, encouraging visitors to stay overnight and increasing LOS should be strategic objectives for tourism management in rural areas. This implies first identifying LOS determinants. Our study analyzed LOS determinants in the SVN area of central Portugal, an area where same-day visitors account for almost half of the total visitor numbers, with the corresponding implications for sustainability. Compared to other studies, the results reveal specific patterns in LOS determinants. Visitor-based variables, such as age, sex, or education, which had been identified as significant determinants of LOS in other tourism typologies [29,50,52], were not found to be significant in our research, either in terms of the decision to stay overnight or in the duration of stay. This indicates the specific nature of tourism in the SVN. As it is an affordable and relatively cheap destination (double room rates range between 45 and 275 EUR per night) [83], variables of a socio-economic nature, such as occupation or income, were not significant LOS determinants, in contrast to the findings of other studies [32,54,84].

However, with divergent impacts, varying visitor motivations significantly determine the decision to stay overnight in the SVN. The components related to the characteristics of the destination's "natural and cultural attractions" (Mot $\left.{ }_{2}\right)$ and "sports and activities" (Mot 3 ) do not contribute to staying overnight at the destination, while those related to the "relaxation and hospitality" (Mot 1 ) and "local produce" $\left(\mathrm{Mot}_{4}\right)$ have a positive effect on the decision to stay overnight in the SVN. The first two components $\left(\mathrm{MOT}_{2}\right.$ and $\mathrm{MOT}_{3}$ ) are related to characteristics of the destination (pull motivation) and point to the existence of some attractions and activities that can be enjoyed in a short period of time and, in many cases, without the need to stay overnight at the destination. The last two components $\left(\mathrm{MOT}_{1}\right.$ and $\mathrm{MOT}_{4}$ ) are related to internal aspects of visitors (push motivation) $[68,70]$ and could be associated with slow tourism. Slow tourism is an alternative form of tourism and, according to [85] (p. 1), focuses "on local contact and nearby sights, consumption of local products and heritage, use of clean energy, ecological and ethical vision, and preserving the quality of life of residents and tourists alike".

The component "relaxation and hospitality" $\left(\mathrm{MOT}_{1}\right)$ was also a significant determinant in the increase in LOS. Resting in a calm and friendly environment would appear to be an important factor in encouraging tourists to spend a longer time at their destinations. Peace and quiet form an important part of the appeal of rural areas, together with access to nature and architectural and cultural resources, which are key elements in attracting a growing group of tourists, usually from large cities seeking a slower, deeper, and more authentic enjoyment of the tourist experience [24,86-88]. On the contrary, the other motivations have no significant influence on the number of overnight stays. As noted above, this may be due to the lack of a sufficient offer of attractions and activities to retain tourists for a longer period of time at the destination. Similarly, the number of villages visited (visits) is a variable that was significant both in terms of staying overnight in the SVN and in terms of the increase in LOS, indicating the need for a large itinerary in order to obtain a tourist product that justifies staying overnight in the destination and a higher LOS.

Visitors from Northern Portugal and the Porto area tend to have the highest LOS. These visitors are those, together with those from the Central region, who are closest to the SVN, thus generating fewer environmental impacts in the form of $\mathrm{CO}_{2}$ emissions due to the reduced distances. This is an interesting result from the point of view of sustainability. Visitors from nearby regions and with a higher probability of staying overnight contribute to a greater net impact of tourism and to combatting climate change and its effects in line with the 2030 Sustainable Development Goals [89]. From the point 
of view of promotion, the word-of-mouth (WOM) recommendations of friends and relatives have emerged as the most significant determining factor when staying overnight in the SVN. In contrast, conventional advertising through audio-visual media and tourist brochures does not have a decisive influence on encouraging visitors to stay overnight or boosting LOS.

Several specific characteristics of the various villages analyzed through variables, such as the importance of tourism in the local economy (tourist activity) or the number of inhabitants of the village (size), also significantly influence the probability of staying overnight in any of the network's villages. As pointed out by [35], visitors seeking contact with the local population, culture, and customs appreciate contact with local producers and consumers. Similarly, the configuration of the tourist offer and the location of the villages within the SVN (region) has proved significant in increasing LOS. Compared to Zêzere (region 4), the probability of staying overnight in the Tejo-Ocreza (region 3) is significantly lower. Zêzere is the region that attracts the highest number of visitors. It is located in the center of the SVN geographical area, is made up of six villages, is the region with the highest resident population, and has a number of major attractions, such as river beaches. In contrast, Tejo-Ocreza is made up of only four villages, only one of which has a resident population, as the other three are used exclusively to accommodate tourists. It is the most remote region and is a passageway to the Zêzere villages, so many of the visitors only spend a short time in this region. The tourist specialization of the Tejo-Ocreza villages means that the duration of LOS of overnight visitors is significantly longer in this region.

The results of our study allow us to draw a series of conclusions and make some recommendations that can serve as a guide for decision-making aimed at increasing both the weight of tourists within the set of visitors and LOS in the SVN. First of all, it is clear that the SVN boasts a number of cultural and heritage resources that are currently highly valued and in considerable demand. This is reflected in visitor behavioral loyalty, measured through the high percentage of repeat visitors. However, the offer of attractions and activities is insufficient in order to attract larger numbers of tourists and increase LOS. Only the motivations that depend on internal conditions of the visitor, such as the search for rest and the preference for local produce, have a significant influence on the decision to stay overnight and increasing LOS. A number of previous studies have identified limited tourist products as one of the weaknesses facing rural tourism $[17,19,21]$. Local stakeholders should expand the range and availability of activities for visitors. This would allow tourists to explore the destination in more depth, extending the economic and social benefits of tourism, whilst reducing environmental impacts and improving tourist satisfaction. The offer of local produce should also be increased in order to take advantage of the current interest in locally sourced goods. The preference for consuming local produce can contribute to maximizing the net effects of tourism in rural areas. As the authors of [90] (p. 42) point out, this trend "helps to preserve the small farms and sustain rural communities as the money spent remains in the local community. It also minimizes food miles, thus cutting down fossil fuel consumption and reducing air pollution". In the SVN, local produce can be purchased in the Schist Village Shops or consumed in the region's various restaurants. There is also an extensive leisure offer that includes sports and adventure tourism, as well as outdoor, cultural, and heritage activities. However, we consider that this offer could be improved with greater cooperation and coordination between the various companies operating in the region (accommodation, catering, leisure and entertainment businesses, etc.). The properties, and even the villages themselves, would also benefit from a policy of specialization based on tourist experiences that use the resources that are specific to each. Efforts should also be made to encourage networking between rural tourism establishments, and public administrations should promote coordinated offers centered on themed itineraries. These measures would improve the offer, boosting its appeal and tailoring it for specific segments of the demand.

Secondly, given that word-of-mouth recommendations were found to be the principal determinant in the decision to stay overnight, regional institutions, operators, and the local population should join forces in order to guarantee optimum visitor satisfaction levels. Overall and attribute satisfaction 
is widely acknowledged as a key determinant for attitudinal loyalty, understood as the intention to revisit and recommend the destination to others [71,91]. Loyalty is important for three reasons: It reduces price sensitivity; the costs of attracting visitors who are familiar with the destination are lower than capturing new visitors; and loyal visitors will attract others through their word-of-mouth recommendations [66,92]. On the contrary, compared to word-of-mouth recommendations, it has been found that conventional advertising is neither effective in getting visitors to stay overnight at the destination or in increasing LOS. This fact indicates the need to reconsider the promotion policies implemented in the SVN to date.

Third, from the point of view of destination management and tourism policies, attracting visitors from nearby regions should be a strategic objective, as [36] pointed out, to maintain income whilst, at the same time, complying with obligations related to climate change. A key strategy would therefore be destination marketing aimed at reducing average journey lengths as well as increasing LOS. Given that visitors from the north of Portugal are those who are more likely to stay overnight at the destination and that those from the center of the country rarely stay overnight given their proximity, we consider that efforts should focus on two main geographic areas. Firstly, the destination should be promoted in Spanish cities close to the SVN, such as Badajoz or Caceres, in order to boost visitor numbers from these cities and increase LOS. The second key area should be southern Portugal and the Lisbon area in particular, which has a significant number of potential visitors. From an environmental point of view, this could contribute to sustainable tourism growth, one of the four key megatrends that tourism will have to face in the coming decades [93].

Finally, it seems clear that certain characteristics of the villages, such as their population size and possibilities for contact with the local culture and traditions, are fundamental determinants in staying overnight at the destination. Various authors have already pointed out the need for local authenticity through actions such as local gastronomic experiences, in order to achieve a more credible rural tourism product [23,94-96]. Similarly, as recently noted by [97] (p. 1), “the tourist-resident relationship is one of the sustainability issues regarding the social aspect of tourism development". Therefore, it will be vital for the villages to retain their population, maintain their traditional functions, and involve the local population in tourism-related activities through social and cultural recreation. This would ensure that visitors stay overnight at the destination and thus contribute to a more sustainable development of the region in which the SVN is located.

Author Contributions: Conceptualization, F.M.-R., J.A.M., and X.A.R.; methodology, F.M.-R., and X.A.R.; software, F.M.-R., and X.A.R.; validation, F.M.-R., J.A.M., and X.A.R.; formal analysis, F.M.-R., J.A.M., and X.A.R.; research, F.M.-R., J.A.M. and X.A.R.; resources, F.M.-R., J.A.M., and X.A.R.; data treatment, F.M.-R., J.A.M., and X.A.R.; writing-original draft preparation, F.M.-R.; writing-review and editing, F.M.-R., J.A.M., and X.A.R. All authors have read and agree with the published version of the manuscript.

Funding: This research received no external funding.

Acknowledgments: The authors would like to thank Rui Simão, Executive Director of the Tourism Development Agency of the Schist Villages Network (ADXTUR) for his cooperation in facilitating access to secondary data and his collaboration with our fieldwork.

Conflicts of Interest: The authors declare no conflict of interest.

\section{References}

1. UNWTO (UN World Tourism Organization) (2020). International Tourism Highlights, 2019 Edition. Available online: https://www.e-unwto.org/doi/pdf/10.18111/9789284421152 (accessed on 9 March 2020).

2. UNWTO (UN World Tourism Organization) (2017). UNWTO World Tourism Barometer, Volume 15, June 2017. Available online: http://mkt.unwto.org/barometer (accessed on 3 March 2020).

3. Belhassen, Y.; Uriely, N.; Assor, O. The touristification of a conflict zone: The case of Bil'in. Ann. Tour. Res. 2014, 49, 174-189. [CrossRef]

4. Freytag, T; Bauder, M. Bottom-up touristification and urban transformations in Paris. Tour. Geogr. 2018, $20,443-460$. [CrossRef] 
5. Sequera, J.; Nofre, J. Debates Shaken, not stirred. New debates on touristification and the limits of gentrification. City 2018. [CrossRef]

6. Del Romero, L. Touristification, Sharing Economies and the New Geography of Urban Conflicts. Urban Sci. 2018, 2, 104. [CrossRef]

7. Jover, J.; Díaz-Parra, I. Gentrification, transnational gentrification and touristification in Seville, Spain. Urban Stud. 2019. [CrossRef]

8. Campos, R.; Sequeira, A. Urban Art touristification: The case of Lisbon. Tour. Stud. 2019, $20,182-202$. [CrossRef]

9. Andrade, M.J.; Costa, J.P. Touristification of European Port-Cities: Impacts on Local Populations and Cultural Heritage. In European Port Cities in Transition Moving Towards More Sustainable Sea Transport Hubs; Carpenter, A., Lozano, R., Eds.; Springer: Basel, Switzerland, 2020; pp. 187-204.

10. Statistical Office of the European Union (EUROSTAT). Database. Available online: https://ec.europa.eu/ eurostat/data/database (accessed on 9 March 2020).

11. Park, D.-B.; Yoon, Y.-S. Developing sustainable rural tourism evaluation indicators. Int. J. Tour. Res. 2011, 13, 401-415. [CrossRef]

12. Stetic, S. Specific features of rural tourism destinations management. J. Settl. Spat. Plan. 2012, 1, 131-137.

13. Woo, E.; Kim, H.; Uysal, M. Life satisfaction and support for tourism development. Ann. Tour. Res. 2015, 50, 84-97. [CrossRef]

14. Muresan, I.; Oroian, C.; Harun, R.; Arion, F.; Porutiu, A.; Chiciudean, G.; Todea, A.; Lile, R. Local residents' attitude toward sustainable rural tourism development. Sustainability 2016, 8, 100. [CrossRef]

15. Androshchuk, L.; Chernenko, N. The economic and mathematical analysis of migration of employable population as a factor of national modernization in crisis. East. J. Eur. Stud. 2016, 7, 35-47.

16. Roberts, L.; Hall, D.; Morag, M. New Directions in Rural Tourism; Routledge: Abingdon, UK, 2017.

17. Castellano-Álvarez, F.J.; Del Río-Rama, M.C.; Álvarez-García, J.; Durán-Sánchez, A. Limitations of Rural Tourism as an Economic Diversification and Regional Development Instrument. The Case Study of the Region of La Vera. Sustainability 2019, 11, 3309. [CrossRef]

18. Yagüe Perales, R.M. Rural tourism in Spain. Ann. Tour. Res. 2002, 29, 1101-1110. [CrossRef]

19. Sharpley, R. Rural tourism and the challenge of tourism diversification: The case of Cyprus. Tour. Manag. 2002, 23, 233-244. [CrossRef]

20. Irvine, W.; Anderson, A.R. Small tourist firms in rural areas: Agility, vulnerability and survival in the face of crisis. Int. J. Entrep. Behav. Res. 2004, 10, 229-246. [CrossRef]

21. Martínez-Roget, F.; Rodríguez, X.A. Occupancy level and productivity in rural tourism establishments: The case of Galicia, Spain. Tour. Econ. 2006, 12, 279-289. [CrossRef]

22. Gascón, J. The limitations of community-based tourism as an instrument of development cooperation: The value of the Social Vocation of the Territory concept. J. Sustain. Tour. 2013, 21, 716-731. [CrossRef]

23. Neumeier, K.; Pollermann, K. Rural tourism as promoter of rural development-Prospects and limitations: Case study findings from a pilot projectpromoting village tourism. Eur. Countrys. 2014, 4, 270-296. [CrossRef]

24. Bel, F.; Lacroix, A.; Lyser, S.; Rambonilaza, T.; Turpin, N. Domestic demand for tourism in rural areas: Insights from summer stays in three French regions. Tour. Manag. 2015, 46, 562-570. [CrossRef]

25. Lane, B. Sustainable rural tourism strategies: A tool for development and conservation. J. Sustain. Tour. 1994, 2, 102-111. [CrossRef]

26. Hall, D.; Richards, G. Tourism and Sustainable Community Development; Routledge: New York, NY, USA, 2003.

27. Cho, H.-S.; Byun, B.; Shin, S. An Examination of the Relationship between Rural Tourists' Satisfaction, Revisitation and Information Preferences: A Korean Case Study. Sustainability 2014, 6, 6293-6311. [CrossRef]

28. Iniesta-Bonillo, M.A.; Sánchez-Fernández, R.; Jiménez-Castillo, D. Sustainability, value, and satisfaction: Model testing and cross-validation in tourist destinations. J. Bus. Res. 2016, 69, 5002-5007. [CrossRef]

29. Barros, C.P.; Machado, L.P. The length of stay in tourism. Ann. Tour. Res. 2010, 37, 692-706. [CrossRef]

30. Rodríguez, X.A.; Martínez-Roget, F.; González-Murias, P. Length of stay: Evidence from Santiago de Compostela. Ann. Tour. Res. 2018, 68, 9-19. [CrossRef]

31. Jacobsen, J.K.S.; Göosling, S.; Dybedald, P.; Skogheim, T.S. Exploring length of stay: International tourism in south-western Norway. J. Hosp. Tour. Manag. 2018, 35, 29-35. [CrossRef]

32. Alegre, J.; Pau, L. The length of stay in the demand for tourism. Tour. Manag. 2006, 27, 1343-1355. [CrossRef] 
33. Fakeye, P.C.; Crompton, J.L. Image differences between prospective, first-time, and repeat visitors to the Lower Rio Grande Valley. J. Travel Res. 1991, 30, 10-16. [CrossRef]

34. Ax, C. Slow consumption for sustainable jobs. In Sustainable Solutions; Charter, M., Tischner, U., Eds.; Greenleaf: Sheffield, UK, 2001; pp. 402-409.

35. Hall, C.M. The contradictions and paradoxes of slow food: Environmental change, sustainability and the conservation of taste. In Slow Tourism. Experiences and Mobilities; Fullagar, S., Markwell, K., Wilson, E., Eds.; Channel View Publications: Bristol, UK; Buffalo, NY, USA; Toronto, ON, Canada, 2012; pp. 53-69.

36. Gössling, S.; Scott, D.; Michael Hall, C. Global trends in length of stay: Implications for destination management and climate change. J. Sustain. Tour. 2018, 26, 2087-2101. [CrossRef]

37. Gössling, S.; Peeters, P.; Ceron, J.-P.; Dubois, G.; Patterson, T.; Richardson, R.B. The eco-efficiency of tourism. Ecol. Econ. 2005, 54, 417-434. [CrossRef]

38. Gössling, S.; Ring, A.; Dwyer, L.; Andersson, A.-C.; Hall, C.M. Optimizing or maximizing growth? A challenge for sustainable tourism. J. Sustain. Tour. 2016, 24, 527-548. [CrossRef]

39. Thrane, C.; Farstad, E. Domestic tourism expenditures: The non-linear effects of length of stay and travel party size. Tour. Manag. 2011, 32, 46-52. [CrossRef]

40. Mayer, M.; Vogt, L. Economic effects of tourism and its influencing factors. An overview focusing on the spending determinants of visitors. Z. Tour. 2016, 8, 169-198. [CrossRef]

41. Divisekera, S. Economics of tourists' consumption behavior: Some evidence from Australia. Tour. Manag. 2010, 31, 629-636. [CrossRef]

42. Divisekera, S.; Deegan, J. An analysis of consumption behavior of foreign tourists in Ireland. Appl. Econ. 2010, 42, 1681-1697. [CrossRef]

43. Gragl, H.; Kokott, J.; Kulessa, M.; Luther, J.; Nuscheler, F.; Sauerborn, R.; Schellnhuber, H.-J.; Schubert, R.; Schulze, E.-D. Climate Protection Strategies for the First Century: Kyoto and Beyond. Special Report; WBGU: Berlin, Germany, 2003.

44. Thomas, C.D.; Cameron, A.; Green, R.E.; Bakkenes, M.; Beaumont, L.J.; Collingham, Y.C.; Erasmus, B.F.N.; Ferreira de Siquira, M.; Grainger, A.; Hannay, L.; et al. Extinction risk from climate change. Nature 2004, 427, 145-148. [CrossRef]

45. Göossling, S.; Scott, D.; Hall, C.M. Inter-market variability in CO2 emission-intensities in tourism: Implications for destination marketing and carbon management. Tour. Manag. 2015, 46, 203-212. [CrossRef]

46. Marrocu, E.; Paci, R.; Zara, A. Micro-economic determinants of tourist expenditure: A quantile regression approach. Tour. Manag. 2015, 50, 13-30. [CrossRef]

47. Turkle, S. Reclaiming Conversation; Basic Books: New York, NY, USA, 2015.

48. Salmasi, L.; Celidoni, M.; Procidado, I. Length of Stay: Price and Income Semi-Elasticities at Different Destinations in Italy. Int. J. Tour. Res. 2012, 14, 515-530. [CrossRef]

49. Ferrer-Rosell, B.; Martínez-Garcia, E.; Coenders, G. Package and no-frills air carriers as moderators of length of stay. Tour. Manag. 2014, 42, 114-122. [CrossRef]

50. Martínez-García, E.; Raya, J.M. Length of stay for low-cost tourism. Tour. Manag. 2008, 29, $1064-1075$. [CrossRef]

51. Nicolau, J.L.; Más, F.J. Simultaneous analysis of whether and how long to go on holidays. Serv. Ind. J. 2009, 29, 1077-1092. [CrossRef]

52. Alegre, J.; Mateo, S.; Pau, L. A latent class approach to tourist's length of stay. Tour. Manag. 2011, 32, 555-563. [CrossRef]

53. Peypoch, N.; Randriamboarison, R.; Rasoamananjara, F.; Solonandrasana, B. The length of stay of tourists in Madagascar. Tour. Manag. 2012, 33, 1230-1235. [CrossRef]

54. Brida, J.G.; Meleddu, M.; Pulina, M. Factors influencing length of stay of cultural tourism. Tour. Econ. 2013, 19, 1273-1292. [CrossRef]

55. Alén, E.; Nicolau, J.L.; Losada, N.; Domínguez, T. Determinant factors of senior tourists' length. Ann. Tour. Res. 2014, 49, 19-32. [CrossRef]

56. Santos, G.E.D.O.; Ramos, V.; Rey-Maquiera, J. Length of stay at multiple destinations of tourism trips in Brazil. J. Travel Res. 2015, 54, 788-800. [CrossRef]

57. Thrane, C. Students' summer tourism: Determinants of length of stay (LOS). Tour. Manag. 2016, 54, 178-184. [CrossRef]

58. Abaladejo Pina, I.P.; Díaz Delfa, M.T. Rural tourism demand by type of accommodation. Tourism Manage. 2004, 26, 951-959. [CrossRef] 
59. Martínez-Roget, F.; Rodríguez, X.A. Rural tourism demand in Galicia, Spain. Tour. Econ. 2006, 12, $21-31$. [CrossRef]

60. Eusébio, C.; Carneiro, M.J.; Kastenholz, E.; Figueiredo, E.; Da Silva, D.S. Who is consuming the countryside? An activity-based segmentation analysis of the domestic rural tourism market in Portugal. J. Hosp. Tour. Manag. 2017, 31, 197-210. [CrossRef]

61. Kastenholz, E. Analysing determinants of visitor spending for the rural tourist market in North Portugal. Tour. Econ. 2005, 11, 555-569. [CrossRef]

62. Moutela, J.A.; Carreira, V.; Martinez-Roget, F. Authenticity in interior rural areas: A systemic study of stakeholders in the Schist Villages Network. In Authenticity \& Tourism: Materialities, Perceptions, Experiences; Rickly, J.M., Vidon, E., Jafari, J., Eds.; Tourism Social Science Series; Emerald Publishing: Bingley, UK, 2018; Volume 24, pp. 109-126.

63. Carvalho, P. A AIBT do Pinhal Interior e as Aldeias do Xisto: Novos caminhos e actores para o desenvolvimento de territórios de baixa densidade en ambientes de montanha. Cadernos Geogr. 2009, 28/29, 185-191.

64. Ramos, B.A. Aldeias do Xisto: Um conceito de turismo sustentável inovador. Rev. Tur. Desenv. 2009, 11, $103-107$.

65. Martínez-Roget, F.; Moutela, J.A. Novas motivações dos turistas: Uma oportunidade para o território rural. Análise da "Rede das Aldeias do Xisto" no Centro de Portugal. Rev. Tur. Desenv. 2013, 19, 99-110.

66. Martínez-Roget, F.; Moutela, J.A.; Estévez, J.C. Chaves do êxito do Turismo em Espaço Rural (TER): Evidências a partir da lealdade turística na Rede das Aldeias do Xisto. Rev. Port. Estud. Reg. 2015, 40, 7-8.

67. Agency for the Tourist Development of Schist Villages (ADXTUR). Available online: https://aldeiasdoxisto. pt/entidade/706 (accessed on 11 February 2020).

68. Yoon, Y.; Uysal, M. An examination of the effects of motivation and satisfaction on destination loyalty: A structural model. Tour. Manag. 2005, 26, 45-56. [CrossRef]

69. Dann, G.M.S. Anomie, Ego-Enhancement and Tourism. Ann. Tour. Res. 1977, 4, 184-194. [CrossRef]

70. Dann, G.M.S. Tourist Motivation: An Appraisal. Ann. Tour. Res. 1981, 8, 187-219. [CrossRef]

71. Chi, C.G.Q.; Qu, H. Examining the structural relationships of destination image, tourist satisfaction and destination loyalty: An integrated approach. Tour. Manag. 2008, 29, 624-636. [CrossRef]

72. Rid, W.; Ezeuduji, I.O.; Pröbstl-Haider, U. Segmentation by motivation for rural tourism activities in the Gambia. Tour. Manag. 2014, 40, 102-116. [CrossRef]

73. Hair, J.H., Jr.; Black, W.C.; Babin, B.J.; Tatham, R.L. Multivariate Data Analysis; Prentice Hall: Upper Saddle River, NJ, USA, 2005.

74. Hair, J.; Money, A.; Page, M.; Samouel, P. Research Methods for Business; John Wiley and Son Ltd.: Chichester, UK, 2007.

75. Park, D.-B.; Yoon, Y.-S. Segmentation by motivation in rural tourism: A Korean case study. Tour. Manag. 2009, 30, 99-108. [CrossRef]

76. Heckman, J. The common structure of statistical models of truncation, sample selection and limited dependent variables models and a simple estimator for such models. Ann. Econ. Soc. Measur. 1976, 5, 475-492.

77. Heckman, J. Sample selection bias as a specification error. Econometrica 1979, 47, 153-161. [CrossRef]

78. Verbeek, M. A Guide to Modern Econometrics, 4rd ed.; Wiley \& Sons: Chichester, West Sussex, UK, 2012.

79. Greene, W.H. Econometric Analysis, 3rd ed.; Prentice Hall Inc.: London, UK, 1998.

80. Wooldridge, J.M. Econometric Analysis of Cross Section and Panel Data, 2nd ed.; The MIT Press: Cambridge, UK, 2010.

81. Wynen, J. Explaining travel distance during same-day visits. Tour. Manag. 2013, 36, 133-140. [CrossRef]

82. Ashworth, G.; Page, S.J. Urban tourism research: Recent progress and current paradoxes. Tour. Manag. 2011, 32, 1-15. [CrossRef]

83. Book in Xisto. Aldeias do Xisto. Available online: https://bookinxisto.com/es (accessed on 3 March 2020).

84. Fleischer, A.; Pizam, A. Tourism constraints among Israeli Seniors. Ann. Tour. Res. 2002, 29, 106-123. [CrossRef]

85. Valls, J.-F.; Mota, L.; Vieira, S.C.F.; Santos, R. Opportunities for Slow Tourism in Madeira. Sustainability 2019, 11, 4534. [CrossRef]

86. Lane, B. Rural tourism: An overview. In The SAGE Handbook of Tourism Studies; Jamal, T., Robinson, M., Eds.; Sage Publications: London, UK, 2009.

87. Farah Atiqah Mohamad Noor, F.A.M.; Nair, V.; Mura, P. Conceptualizing a Framework for Slow Tourism in a Rural Destination in Malaysia. Adv. Sci. Lett. 2015, 21, 1185-1188. [CrossRef] 
88. Hjalager, A.-M.; Kwiatkowski, G.; Larsen, M.Ø. Innovation gaps in Scandinavian rural tourism. Scandin. J. Hosp. Tour. 2018, 18, 1-17. [CrossRef]

89. United Nations. Sustainable Development Goals. 2020. Available online: https://www.un.org/ sustainabledevelopment/ (accessed on 23 February 2020).

90. Alias, A.; Aziz, A.; Karim, M.S.A.; Isa, S.S. Local food consumption at ecotourism destination. In Adventure and Ecotourism in Malaysia; Mariapan, M., Isa, S.S., Aziz, N.A.A., Lin, E.L.A., Hakeem, K.R., Eds.; Faculty of Forestry: Selangor, Malaysia, 2015; pp. 40-45.

91. Kim, K.-H.; Park, D.-B. Relationships among Perceived Value, Satisfaction, and Loyalty: Community-Based Ecotourism in Korea. J. Travel Tour. Mark. 2017, 34, 171-191. [CrossRef]

92. Oppermann, M. Tourism Destination Loyalty. J. Travel Res. 2000, 39, 78-84. [CrossRef]

93. OECD. OECD Tourism Trends and Policies; OECDE Publishing: Paris, France, 2018. [CrossRef]

94. Sidali, K.; Kastenholz, E.; Bianchi, R. Food tourism, niche markets and products in rural tourism: Combining the intimacy model and the experience economy as a rural development strategy. J. Sustain. Tour. 2015, 23, 1179-1197. [CrossRef]

95. Flanigan, S.; Blackstock, K.; Hunter, C. Agritourism from the perspective of providers and visitors: A typology-based study. Tour. Manag. 2014, 40, 394-405. [CrossRef]

96. Pulido-Fernández, J.I.; Ward-Perkins, D.; Krukova, O.V. Nature-Based Tourism. In Tourism in Russia: A Management Handbook; Diamanche, F., Andrades, L., Eds.; Emerald Group Publishing Limited: Bingley, UK, 2015; pp. 181-230.

97. Lai, I.K.W.; Hitchcock, M.; Lu, D.; Liu, Y. The Influence of Word of Mouth on Tourism Destination Choice: Tourist-Resident Relationship and Safety Perception among Mainland Chinese Tourists Visiting Macau. Sustainability 2018, 10, 2114. [CrossRef]

(C) 2020 by the authors. Licensee MDPI, Basel, Switzerland. This article is an open access article distributed under the terms and conditions of the Creative Commons Attribution (CC BY) license (http://creativecommons.org/licenses/by/4.0/). 